\title{
Analysing potato late blight control as a social-ecological system using fuzzy cognitive mapping
}

\author{
Francine C. A. Pacilly ${ }^{1}$. Jeroen C. J. Groot ${ }^{1}$ - Gert Jan Hofstede ${ }^{2}$. \\ Ben F. Schaap ${ }^{3}$. Edith T. Lammerts van Bueren ${ }^{4}$
}

Accepted: 18 April 2016/Published online: 18 May 2016

(C) The Author(s) 2016. This article is published with open access at Springerlink.com

\begin{abstract}
Potato late blight, caused by Phytophthora infestans, is one of the main diseases in potato production, causing major losses in yield. Applying environmentally harmful fungicides is the prevailing and classical method for controlling late blight, thus contaminating food and water. There is therefore a need for innovative research approaches to produce food sustainably. Here, we used a systems approach to identify sustainable management strategies for disease control in potato production in the Netherlands. We focussed not only on ecological processes, the classical approach, but also on decision-making concerning disease management. For that, we performed a literature study, stakeholder interviews and modelling using fuzzy cognitive mapping. Interviews were carried out with farmers, representatives of breeding companies and experts. The fuzzy cognitive map allows to identify major concepts and their influence on late blight management. Three management scenarios were analysed using the fuzzy cognitive map. Results show that published research on the control of potato late blight focusses on agronomic practices, plant breeding for resistance to late blight and chemical-based disease suppression. Farmers are strongly influenced by corporate (such as traders, breeders
\end{abstract}

Francine C. A. Pacilly

francine.pacilly@wur.nl

1 Farming Systems Ecology, Wageningen University, P.O. Box 430, Wageningen, The Netherlands

2 Information Technology, Wageningen University, P.O. Box 8130, 6700 EW Wageningen, The Netherlands

3 Wageningen UR Agrosystems Research, P.O. Box 16, 6700 AA Wageningen, The Netherlands

4 Wageningen UR Plant Breeding, P.O. Box 386, 6700 AJ Wageningen, The Netherlands and retail) and public institutes and policies, each pushing their own objectives and interests. The fuzzy cognitive map showed that social and ecological processes are tightly related. The scenario analysis showed that increasing stakeholder cooperation and a change in market demands towards resistant cultivars could improve sustainability of late blight management. In contrast, policies restricting the use of fungicides would result in increased disease severity if no alternative strategies were implemented. Adoption of such strategies would require social-institutional support and facilitation. We conclude that our systems approach improves the understanding of the system dynamics which is necessary for developing and deploying effective strategies for controlling P. infestans.

Keywords Phytophthora infestans - Cropping systems · Sustainable disease management $\cdot$ Potato production chain . Socio-institutional interactions

\section{Introduction}

The Netherlands is a large producer of seed, ware and starch potatoes, and therefore, potato is an economically important crop (Haverkort et al. 2008). Due to the high density of potatoes and favourable weather conditions, late blight (caused by Phytophthora infestans) is one of the most important diseases in potato production. Infection by $P$. infestans results in foliage death and tuber rot in the field and during storage, which leads to major losses in yield. The pathogen has a short life cycle that can be completed in less than a week and potentially produces large quantities of spores. As a result of wind dispersal of the spores, and the potentially large number of generations, a late blight epidemic can spread over large regions in a short time (Zwankhuizen and Zadoks 2002). Currently, 
the use of fungicides is the most important method to control blight, but this involves high costs and the fungicides are harmful for the environment (De Jong and De Snoo 2002; Van Der Werf 1996). The environmental costs are related to the pollution of groundwater, energy costs for application and negative effects on human health (Haverkort et al. 2008). In addition, about half of all fungicides applied in the Netherlands is used for the control of potato late blight as often weekly sprayings are needed. Regarding the options in disease control, a strong difference exists between organic and conventional farmers. In contrast to other European countries, the use of copper as fungicide is not permitted in the Netherlands so organic farming systems have no chemical means to combat late blight. Therefore, yields can be dramatically low in years of early outbreak of late blight. To reduce the amount of fungicides in conventional systems and to improve disease control for organic farmers, the development of resistant cultivars is a top priority (Finckh et al. 2006).

Late blight-resistant cultivars of potato developed by commercial breeding companies can play a key role in sustainable management of potato late blight (Fig. 1). Breeding for resistant cultivars started in the beginning of the twentieth century when the first resistant genes (R-genes) were discovered in the closely related species Solanum demissum (Fry 2008). Unfortunately, when cultivars with these resistant genes came to be more widely grown, the R-genes from $S$. demissum have been broken as a result of pathogen evolution. Currently, several new resistance genes from different genetic resources are being used in classical breeding programmes to develop new resistant cultivars (Lammerts Van Bueren et al. 2008). Breeding for varieties with resistant genes from wild relatives is time consuming, so additional management practices are

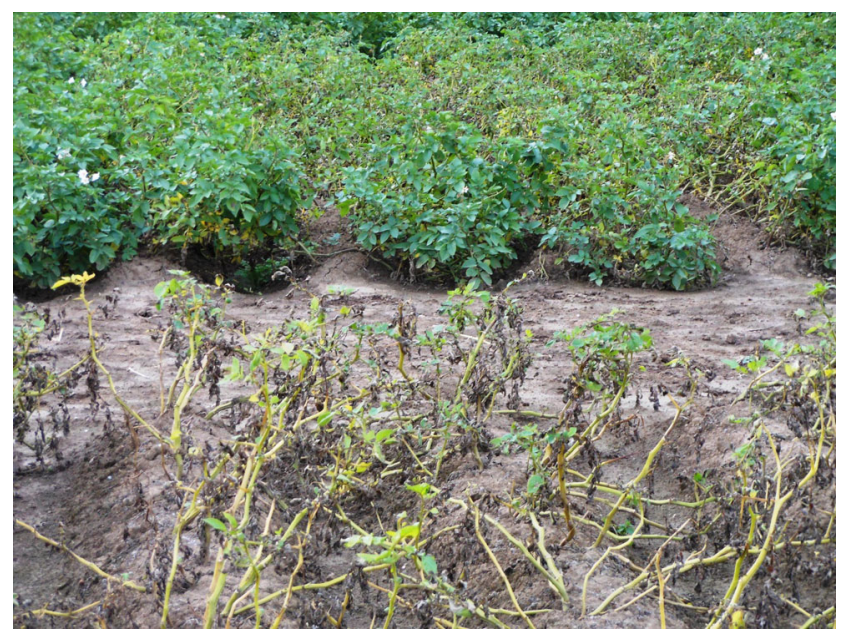

Fig. 1 A picture showing the difference in late blight infection in susceptible and resistant potato cultivars. The susceptible cultivars in the front are almost completely destroyed by late blight, while the resistant cultivars in the back are not harmed by the disease required to protect new resistance genes in cultivars from resistance breakdown.

In management of potato late blight, farmers play a key role since they make decisions on crop management. In adopting management strategies, farmers are also influenced by other stakeholders such as breeding companies, traders and policy makers, who have their own objectives and interests. For example, farmers try to optimise their profits, breeding companies aim to increase their return on investment and the government facilitates sustainable food production. Farmers are also affected by the management strategies of other farmers since infections in one field can spread by wind to neighbouring uninfected potato fields. Due to high density of potato, the Dutch government has implemented a policy that regulates maximum late blight disease thresholds. At an estimated $5 \%$ infected leaf area per field, the potato haulm has to be destroyed to prevent spread to neighbouring fields (PA 2008). In years with early outbreak, this can cause severe yield loss and farmers tend to delay the moment of defoliation. Therefore, late blight management is also a social problem with related issues such as trust, social pressure and conflicts.

Overall, the disease incidence in a landscape is the result of interactions between plants and pathogens through disease epidemiology as well as stakeholder behaviour (Rebaudo and Dangles 2012). Therefore, to identify sustainable management strategies of potato late blight, it is important to consider both biophysical and social aspects and their interactions. Also in our definition of sustainability, we consider environmental, economic and social consequences of management practices, because alternative strategies that could reduce the environmental impact of disease management must also be practically and economically attractive for successful implementation (Thierfelder et al. 2013; Duru et al. 2015a; Sadok et al. 2008).

The objective of the paper is to provide an overview of the system components and their interactions and important drivers of the system. To analyse and describe the components, the interactions and feedback mechanisms related to late blight management in the Netherlands, three different methods were used: (1) literature review on late blight management, (2) semi-structured interviews with stakeholders and (3) a modelling exercise called fuzzy cognitive mapping. With fuzzy cognitive mapping as a semi-quantitative method, the main components of the system identified could be modelled (Kok 2009). We developed three different scenarios for stakeholder management and control of late blight. The effect of the scenarios on late blight severity was analysed using the fuzzy cognitive map.

First, we present an inventory of the existing research and approaches for late blight control, then we analyse the importance of the social-institutional context of potato cultivation and disease management and last we discuss the relevance of an integrated social-ecological perspective. 


\section{Materials and methods}

In this paper, late blight management in the Netherlands is analysed, and the system components, interactions and feedback mechanisms are identified and described. Current research on late blight management was analysed to identify important aspects in the control of late blight. A brief literature review was carried out to analyse articles related to management of potato late blight. These articles discussed several aspects that were divided into categories. The main findings for each category were described and expert knowledge was used to include relevant literature missing in the analysis.

Semi-structured interviews were carried out to identify current management strategies in the Netherlands, stakeholder objectives and factors involved in decision-making. Semistructured interviews were carried out with representatives of breeding companies, farmers and experts. Five representatives of two of the largest Dutch breeding companies were interviewed to identify their organisational structure, marketing strategies and breeding programmes in relation to resistance of potato to late blight. In total, 25 farmers were interviewed by using semi-structured interviews on topics such as general farm characteristics, their social network, problems in potato production, current late blight management strategies and the use of late blight-resistant cultivars. A stratified sample of farmers was selected based on region, farmer type (conventional/organic) and diversity in management. In total, 18 conventional and 7 organic farmers were interviewed mainly from the northern part of the Netherlands. This is an important potato-growing region that includes the production of seed, ware and starch potatoes. Most of the organic farmers were located in the province of Flevoland, an agricultural region with a relative large number of organic farming systems.

Both organic and conventional farmers were included since these groups differ in their options for control measures and may also differ in their decision-making and interest in disease control strategies. Based on the results from the interviews, we identified the main differences in management strategies between farmers and the drivers involved in their decision-making processes. Two experts, a researcher specialised in plant diseases and a farm consultant, both familiar with organic and conventional productions systems, were interviewed to develop a broad perspective on the issues in potato production and late blight management as well as differences in the management strategies of farmers. All interviews were recorded and transcribed for further analysis.

After the main components of the system had been identified using the results from the literature review and interviews, the system was modelled in a semi-quantitative tool called fuzzy cognitive mapping (Kok 2009). Fuzzy cognitive mapping is a computational modelling technique that represents the main components, processes and drivers of the system (concepts) as well as their causal relationships. The relationships can be defined as positive or negative, and to each relation, a weighting factor is assigned. The weight quantifies the strength of the relationship between the concepts and is a number between -1 and +1 . Weighting factors were divided in four groups representing weak (0.1), medium (0.25), strong (0.5) and very strong $(0.75)$ relations with a positive or negative effect. For every simulation time step, the value of the concepts will be updated by using a matrix calculation. The new state can be calculated by multiplying the state vector, which contains all the concept state values, with the adjacency matrix, including the values of all the relations between concepts. This process can be repeated indefinitely which can result in several patterns. Therefore, the simulation time step represents the number of iterations of the matrix calculation. Usually, it takes 20-30 iteration steps to determine the pattern. When the model output results in an equilibrium, the values of the concepts in the stable state can be compared for different model settings. Fuzzy cognitive mapping is called semi-quantitative because the values of model variables can only be compared relatively to other numbers. Furthermore, the iteration step cannot directly be translated to time since the processes in the model usually act on different scales.

After developing a first draft of the fuzzy cognitive map, a workshop with experts was organised to validate the map. Organising workshops with stakeholders is a common approach in the development of a fuzzy cognitive map because the model will represent a consensus of various opinions (Kok 2009). Since the goal of the model is to get an overview of the system, the workshop with experts was used to validate the important concepts and relations. Six experts took part in the workshop with different specialisations including hostparasite interactions, plant pathology, plant breeding, agronomy, agro-industrial chains and climate change and agriculture. In general, the results from the workshop supported the initial model version, but based on the workshop discussions, some modifications were made to summarise similar concepts and to better represent causal relationships. To determine the contribution of a concept in a fuzzy cognitive map, the centrality was calculated, which shows to what extent the concept is connected to other concepts (Özesmi and Özesmi 2004). The centrality is calculated by the summation of its indegree (in-arrows) and outdegree (out-arrows) in which the absolute weight of all incoming and outgoing relations is summed. The indegree and outdegree can be used to determine if the concept mainly influences other concepts (a 'transmitter' with high outdegree), is mainly influenced by other concepts (a 'receiver' with high indegree) or both. 


\section{Results and discussion}

\subsection{The ecological system of potato and $P$. infestans}

In the scientific literature, many aspects and analyses were described related to late blight management. These research topics were divided into categories and described in the following sections. Most of the research on the potato late blight system has been focussed on the primary characteristics of the plant and its pathogen, the host-pathogen interactions, and on the most effective measures to directly suppress the pathogen. This has resulted in many studies analysing the genetics of P. infestans (Section 3.1.1), the development and application of chemical fungicides (Section 3.1.2) and the late blight resistance of potato through breeding or genetic engineering (Section 3.1.3). Alternative measures such as cultivar diversity and host distribution (Section 3.1.4), biological control (Section 3.1.5) and indirect strategies to build plant robustness through for instance soil fertility (Section 3.1.6) have been studied less. Integrated approaches that exploit the diversity of management approaches have been analysed in field experiments, and models have been used to analyse those approaches in patterns in space and time (Section 3.1.7). These approaches are however more complex to implement but can be supported by tools like computer-based decision support systems (Section 3.1.8). A separate line of research concerns the effects of environmental condition such as climate change (Section 3.1.9), which can potentially be relevant for the whole late blight-potato system and the effectiveness of all disease suppression approaches.

\subsubsection{P. infestans population structure and diversity}

The genetic research investigated the diversity and aggressiveness (virulence) of the pathogen. The plasticity of pathogenicity in the genome of $P$. infestans results in rapid adaptation and the ability to overcome both the sensitivity to fungicides and the resistance of potato plants to the disease (Goodwin et al. 1995). P. infestans has different mating types, called A1 and A2. For a long time after its establishment in 1845 , only one mating type (A1) was present in Europe (Fry 2008). The second mating type (A2) was probably introduced by a shipment of potatoes in 1976/1977. With both mating types present, the pathogen was also able to reproduce sexually resulting in the formation of oospores that can survive in the soil for some years (Olanya et al. 2009). New molecular diagnostic tools allowed the analysis of $P$. infestans isolates to examine the genetic diversity (Cooke and Lees 2004). These methods also allow easy determination of mating type and virulence related to resistant cultivars and fungicides. In recent years, the $P$. infestans population structure has been analysed in many countries in Europe, Asia and South America and the USA and Canada and is in some cases also being monitored over time (Harbaoui et al. 2013; Li et al. 2013). This research showed that in many potato-growing regions, the $P$. infestans population is dominated by a few genotypes, which can be stable for several years (Peters et al. 2014) or change rapidly over time (Cooke et al. 2012). Monitoring $P$. infestans population structure and change could be useful in making decisions on disease management with respect to cultivar selection and fungicide application. For example, in the USA, a reduced use of fungicides was associated with the recurrence of mefenoxam-sensitive strains which can have practical implications for late blight management (Hwang et al. 2014). Also, when new P. infestans strains emerge that are insensitive to certain fungicidal compounds or contain compatible virulence genes of certain resistant genes, countermeasures can be taken to prevent further spread of these populations. This can mean switching to other types of fungicides or to cultivars with different resistance genes till these specific traits are no longer found in the $P$. infestans population. This type of management has not yet been put into practice but could be promising for the future.

\subsubsection{Chemical control}

The application of fungicides is currently the most important strategy in the control of late blight by farmers in the Netherlands. Several types of fungicides exists for foliar and tuber treatments. These can be contact or systemic fungicides that have a protective and/or curative effect (Gossen et al. 2014). Most research on fungicides focusses on their effectiveness against late blight, but also performance related to spraying schedules and application methods have been investigated. In the Netherlands, most fungicides are used as a preventive measure. $P$. infestans strains can also become insensitive to fungicides as was found in the case of the fungicide metalaxyl (Gisi and Cohen 1996). Insensitivity to this fungicide is now found all over the world and research was carried out to collect more information on metalaxyl-resistant strains such as their mating type, aggressiveness, etc. In many countries, metalaxyl is no longer used or only in combination with other fungicides. Many different fungicides exist but researchers continue to search for new active compounds (Merk et al. 2011). Fungicide manufacturers try to improve the durability of fungicides by combining active compounds. They also advise farmers to use fungicides with different modes of action over the season to reduce the risk for emergence of resistant strains.

\subsubsection{Resistant cultivars}

An important aspect in sustainable management strategies is the use of resistant cultivars. Regarding their use, many different aspects were investigated such as the mechanisms related to host defence and the identification of resistance genes 
(Bengtsson et al. 2014; Rauscher et al. 2006). Breeding for resistance to late blight started a long time ago. In the classical approach, wild late blight-resistant potato species are crossed with modern cultivars. This introgression process is time consuming: it can take some 16-20 years before a new genitor is available for commercial breeding and multiplication. The genitors are used to develop resistant cultivars which can result in cultivar release on the market. When breeding for resistance, it is important to focus not only on foliar resistance but also evaluate tuber resistance, since these are not always correlated (Park et al. 2005). With a technique based on genetic engineering called cisgenesis or intragenesis, it is possible to introgress resistant genes from wild potato species directly into existing cultivars (Haverkort et al. 2008). This method is faster compared to classical breeding programmes, but this technique does not seem to work with all existing cultivars and also the long-term effect of these insertions is unknown. Because many resistant genes have been overcome by the pathogen in the past, researchers continue to search for new and more durable ones. One of the strategies emphasised is breeding for combined (stacked) resistance genes from different genetic resources, but this is even more time consuming and costly than breeding for cultivars with a single resistant gene. It is also yet unknown whether a combination of two, three or four genes is needed to prevent breakdown of resistance (Tan et al. 2010).

\subsubsection{Cultivar diversity and host distribution}

The use of resistant cultivars in the control of late blight was analysed in field experiments and simulation models. Recent research insights into the spatial epidemiology of $P$. infestans suggested that major advances in reduction of the disease could be achieved by combining traditional (chemical) methods of disease control with spatial management of resistant cultivars at field to regional scales (Skelsey et al. 2010). A spatially explicit simulation model of $P$. infestans dispersal in potato cultivar mosaics was used, which showed that an increase in the area of resistant cultivars was very effective in suppressing the spread of the disease. Mixing susceptible and resistant cultivars on small scales (at plant and row levels) was most effective in decreasing disease spread. Field experiments with intercropping systems or mixed susceptible and resistant potato cultivars often resulted in significant reductions of the disease but have not been able to eradicate it completely (Andrivon et al. 2003; Garrett and Mundt 2000).

\subsubsection{Biological control}

The use of chemical fungicides in the control of late blight has always been under debate because of the high frequency of application and amount used in the control and the negative effect they can have on the environment and to the people that work with them (Haverkort et al. 2008). This, and the fact that the application of chemical fungicides is not allowed in organic potato production, makes it of great importance to keep searching for other biological control methods such as biocontrol agents, plant extracts and biopesticides. These biological methods were applied as seed, foliar and/or tuber treatment to assess their ability to suppress late blight. Some of these compounds have been proven to be effective; however, none of them work as well as regular fungicides (Gachango et al. 2012; Olanya and Larkin 2006; Shanthiyaa et al. 2013). However, these practices could contribute to sustainable management, and therefore, it has been suggested to combine these practices with other biological, cultural and fungicide approaches (Glare et al. 2012).

\subsubsection{Soil management}

Another example of an alternative strategy is soil management. Soil management, including fertiliser application, can have an effect on plant growth and physiology, which can influence host defence responses (Cicore et al. 2012). For example, in vitro studies showed that nitrogen supply increased susceptibility of potato to $P$. infestans; however, under field conditions, no effect was observed. Furthermore, management strategies could affect antagonistic microorganisms in the soil that inhibit infection of $P$. infestans (LozoyaSaldaña et al. 2006; Tamm et al. 2010). In the case of $P$. infestans, under environmental conditions, oospores can survive in the soil for about 3 to 4 years, and if potatoes are grown within this period, initial infection as a result of the presence of residual oospores can occur (Turkensteen et al. 2000). In the Netherlands, infections originating from oospores were mainly found in potato-producing regions with narrow rotation schemes, and therefore, a bigger rotation scheme is recommended to prevent such sources of infection (Evenhuis et al. 2007).

\subsubsection{Integrated disease management}

Integrated disease management is described as a combination of methods to limit the use of chemical fungicides to a minimum (Schöber 1992). Because many of the previously described strategies such as intercropping or fungicide application result in ineffective or unsustainable control, these can be combined to improve disease management. The use of resistant cultivars is an important component in integrated disease management, and it has been analysed how these can be combined with other strategies. Strategies included in integrated disease management research are for example host resistance, host density and diversity, seed tuber pre-sprouting and application of fungicides (Möller and Reents 2007; Mundt et al. 2002). In another study, also planting time was part of an integrated approach in combination with fungicide application 
and host resistance (Kankwatsa et al. 2002). Field experiments that combined host resistance and fungicide use showed that the disease could be controlled with less fungicides by lowering the fungicide dose or longer application intervals (Kirk et al. 2005; Nærstad et al. 2007). Integrating these two types of management strategies was already analysed by Fry (1977), and recently, this approach was also used in combination with cisgenic resistant potatoes (Haverkort et al. 2016).

\subsubsection{Decision support systems}

Decision support systems (DSS) have been developed with the aim of optimising the use and timing of fungicide application in order to achieve efficient spraying and to prevent fungicide insensitivity (Wharton et al. 2008). For more information on the development and availability of DSS and the adoption and use by farmers, we refer to the following two references (McCown 2002; Shtienberg 2013). Overall, these systems use several types of information such as the crop condition and weather data such as temperature, wind speed, rainfall and humidity to estimate the risk of $P$. infestans infection and to predict outbreaks. Not all systems take cultivar resistance into account (Grünwald et al. 2000) while this is an important factor for estimating infection risk. Recently, attempts have been made to update these systems with information on spore dispersal by monitoring airborne inoculum (Fall et al. 2015). Spores can be monitored by spore sampling networks for early detection of incoming inoculum. This type of information can be used to optimise the timing of fungicide application. However, model-based analyses performed by Skelsey et al. (2009) showed that adding information on spore dispersal in DSS is only useful in the case of (partially) resistant cultivars. This is because the risk for infection in susceptible cultivars is high and achieving the accuracy of dispersal information required to make reliable decisions on disease management is practically unfeasible. In the case when only susceptible cultivars are grown on a field, already a very low spore input resulted in yield loss; so, to make decisions on disease management, it is risky to rely strongly on spore dispersal information.

\subsubsection{Effects of climatic conditions and climate change}

Weather conditions constitute the most important factor influencing growth and spread of potato late blight. Optimum conditions for late blight include high humidity and a temperature of about $20^{\circ} \mathrm{C}$ (Crosier 1934). Wind is responsible for the dispersal of the spores. Most of these spores will be deposited only a few metres from the initial source, but dispersal across large distances can also take place. Sunlight has a negative effect on $P$. infestans since ultraviolet light will damage the spores. More information on the effect of weather variables on the developmental stages of $P$. infestans can be found in the following references (Andrade-Piedra et al. 2005; Mizubuti et al. 2000; Mizubuti and Fry 1998).

It is well known that climate change can increase the severity of plant diseases (Gautam et al. 2013). Changes in temperature, atmospheric moisture content and $\mathrm{CO}_{2}$ concentration can affect processes related to pathogen growth, reproduction and survival. Furthermore, these factors can also affect the application and effectiveness of current management practices (Schaap et al. 2011). For example, dry weather is required for the application of fungicides. Recently, for the Dutch context, new climate change scenarios of the Royal Netherlands Meteorological Institute have been published in the KNMI'14 scenarios (Van den Hurk et al. 2014) which showed minor changes in humidity for all four scenarios, the main factor influencing the establishment of the pathogen. Most scenarios even showed a decrease in humidity with a maximum of $3.0 \%$, while only in one scenario, humidity increased with $0.1 \%$. Therefore, it is not expected that climate change will have a strong effect on late blight severity in the Netherlands. However, unpredicted side effects can play a role. For example, mild winters can have a positive effect on the survival of inoculum in the soil, which can lead to outbreaks early in the season (Gautam et al. 2013). Therefore, the effect of climate change should be closely monitored in the future.

\subsection{The social system of potato cultivation and late blight management}

From the previous section, we conclude that a diversity of management strategies exists that mainly focusses on the host-pathogen interactions and the most effective measures to directly suppress the disease. In this section, we will focus on the social aspects and aim to give an overview of the Dutch potato sector with the important stakeholders and their objectives and interactions in relation to late blight management. We will start by providing a description of the Dutch potato sector that includes many stakeholders involved in different aspects of the potato production and supply chain (Section 3.2.1). We will describe how the market demand influences which potato types and cultivars are produced and thus how the market demand affects disease susceptibility. Secondly, we will give an overview of the stakeholders involved in late blight management (Section 3.2.2). Farmers play a key role since they have to make decisions on late blight management but are influenced by other stakeholders with specific objectives. We will describe differences between farmers, current management practices and the factors influencing decision-making (Section 3.2.3) and aim to give an overview of the most important interactions. In the last section, we will show that different objectives and interests 
by stakeholders make it difficult to introduce new strategies in the control of late blight (Section 3.2.4).

\subsubsection{Dutch potato sector}

Many stakeholders are involved in the production of seed, ware and starch potatoes in the Netherlands (Table 1). They are involved in different aspects of the production and supply chain including cultivar availability, crop management, potato production, processing and marketing. Breeding companies are responsible for developing new potato cultivars and are usually connected to a trading company. Potatoes are grown for different markets (table, chips, fries, etc.) and each of them requires specific potato traits. Therefore, breeding companies select for many different characteristics of which late blight resistance is only one. Other characteristics include yield, nutrient requirements, shape, storage characteristics, cooking and baking quality and resistance to other pests and diseases (Tiemens-Hulscher et al. 2013). Trading companies are in charge of marketing the potatoes to a variety of clients with specific market demands. Many of the seed potatoes are exported worldwide and only a part remains in the Netherlands to produce ware and starch potatoes for the industry and/or retail. In the production chain, between the trading company and the end-user, potatoes can cross several more actors involved in distribution, packaging and handling. In this system, trading companies play a key role since they form a link between the market demands, the breeding companies and the farmers. They have contracts with customers worldwide as well as with the processing industry.
The variation in demand leads to a production of more than 400 different cultivars in the Netherlands (Lammerts Van Bueren and Van Loon 2011). In general, only a few cultivars are produced in large numbers, while the majority of cultivars are used for niche markets. An extreme case is found in Belgium, where cultivar Bintje occupies about $50 \%$ of the cultivated potato area (De Blauwer and Florins 2014). Apart from positive traits as both table and processing potato, this cultivar is also notorious for its susceptibility to many diseases including late blight. For the industry and retail, traits such as tuber and cooking quality have a high priority, while the agronomic characteristics of the cultivar, including disease susceptibility, are of secondary importance. We learned from the semi-structured interviews that once supply chain parties are accustomed to certain cultivars that meet the market requirements, it is hard to introduce new cultivars due to inflexibility of the supply chain. Therefore, the introduction of new cultivars is a long process and requires large investments from breeding companies. One of the interviewed experts formulated this as following: 'In the past we have seen a lot of cultivars coming and going. So if trading companies have a few cultivars that serve the market well, they don't say goodbye to these cultivars quickly when somebody is suddenly very enthusiastic about a new resistant cultivar. These new cultivars have to be introduced and well accepted by the market.'

\subsubsection{Potato production and management}

Farmers have to make decisions on crop management but they are also influenced by other stakeholders. The agro-chemical

Table 1 Overview of stakeholders with their role in potato production and objectives, based on interviews and literature

\begin{tabular}{|c|c|c|}
\hline Stakeholder & Role in production chain & Objectives \\
\hline Farmers & $\begin{array}{l}\text { - Potato production } \\
\text { - Potato management }\end{array}$ & $\begin{array}{l}\text { - Maximise profit and minimise risks } \\
\text { - Easy and sustainable potato production }\end{array}$ \\
\hline Breeding companies & - Cultivar availability & $\begin{array}{l}\text { - Maximise profit } \\
\text { - Breeding potatoes with different traits to serve markets worldwide }\end{array}$ \\
\hline Trading companies & - Potato marketing & $\begin{array}{l}\text { - Maximise profit } \\
\text { - Quick and wide application of new potato cultivars } \\
\text { - Follow worldwide markets } \\
\text { - Protect cultivars from resistance breakdown }\end{array}$ \\
\hline Processing industry & $\begin{array}{l}\text { - Potato processing } \\
\text { - Potato marketing } \\
\text { - Potato demand }\end{array}$ & $\begin{array}{l}\text { - Maximise profit } \\
\text { - Require potatoes with specific traits }\end{array}$ \\
\hline Retail & $\begin{array}{l}\text { - Potato marketing } \\
\text { - Potato demand }\end{array}$ & $\begin{array}{l}\text { - Maximise profit } \\
\text { - Follow consumer preferences }\end{array}$ \\
\hline Agro-chemical industry & - Potato management & $\begin{array}{l}\text { - Maximise profits } \\
\text { - Develop and market fungicides } \\
\text { - Prevent fungicide insensitivity }\end{array}$ \\
\hline Consumers & - Potato demand & - Cheap, healthy and attractive products \\
\hline Government & - Potato management & $\begin{array}{l}\text { - Protect public health and the environment } \\
\text { - Reduce late blight infection pressure }\end{array}$ \\
\hline Research institutes & - Potato management & - Improve sustainability of late blight management \\
\hline
\end{tabular}


industry is responsible for the production and distribution of fungicides. They advise farmers which fungicides to use over the season for effective control and to prevent fungicide insensitivity. This requires social organisation in which manufacturers and farm advisors play a central role. Research institutes have another objective; they aim to improve sustainability of late blight management by developing new strategies (see Section 3.1). However, many of the strategies investigated are not (yet) commercially available (e.g. biological control), still in an early stage (e.g. late blight monitoring) or do not fit within the current production system (e.g. intercropping with resistant cultivars or other crops that are non-hosts).

Resistant cultivars could contribute to sustainable disease management. We learned from the interviews that the recently introduced late blight-resistant cultivars were not attractive to all farmers as they lack some of the preferred market characteristics. For example, an organic farmer stated that: 'We also tried to grow a resistant cultivar on a few hectares but at a certain moment we were not able to sell them anymore to the market.' Furthermore, the current resistant cultivars are not as high yielding as some of the established cultivars. Therefore, the market demand for current resistant varieties is still low, and because the application of fungicides leads to effective and cheap control, there is no strong economic incentive to make use of late blight resistance in the conventional sector. In the organic sector, the use of resistant cultivars is more promising according to stakeholders, since there is a strong need for alternative control methods. However, this sector is responsible for only $\pm 2 \%$ of the total potato production in the Netherlands (CBS 2014), which can be considered a small market.

Using cisgenic cultivars could potentially contribute to solving problems related to cultivar demand, since resistant genes from wild potato species could be introgressed into already established and existing cultivars that supply a large part of the market. However, the current European regulations consider this technique as genetic modification and the growth and production of these cisgenic potatoes is strictly regulated. To obtain permission to produce cisgenic potatoes, a risk assessment should be carried out to ensure these crops are not harmful for the environment and human and animal health. Besides the possible negative effects for the environment, this topic is also under political and societal debate (Jochemsen 2008). One of the issues is related to the intellectual property rights, also known as plant variety rights and patents (Louwaars et al. 2009). Cisgenesis is an expensive breeding tool, and therefore, the biotechnical industry seeks to protect their technical invention by patents. Possibly, this could have a negative effect on the breeding sector because it is not allowed to use these cultivars in breeding programmes without permission of the patent owner. Examples in other crops show that as a result of patent positions, only a few companies are in control of a large part of the world market which threatens innovation in plant breeding. Therefore, changing the regulations regarding the production of cisgenic crops also includes institutional changes related to these products.

The Dutch government influences late blight management also in other ways. Over time, policies have been introduced to reduce negative environmental impact of fungicides (Staal et al. 2014). Type and amount of active compounds are regulated for use over the years, and this has reduced the pressure on the environment. As mentioned earlier, the introduction of sanitary regulations by the government also helps keeping disease pressure low by mandatory rules for prevention and removal of infected sources. This includes covering cull piles and removing infection sources in potato fields as well as removing volunteers. An inspection was set up that could fine farmers in case these regulations were not followed.

\subsubsection{Farmers}

Farmers are the key stakeholder in the production and management of potatoes. In the Netherlands, around 9000 farms grow potatoes on a total area of about $1500 \mathrm{~km}^{2}$ (CBS 2014). These farmers can be subdivided based on the type of potato they produce (seed, ware or starch potatoes) and the way of cultivation (conventional or organic).

There is a large difference in late blight management between conventional and organic farmers. For conventional farmers, the application of fungicides is the most important control method, sometimes supported by the use of DSS. In contrary to other countries, in the Dutch organic sector, neither the use of synthetic chemicals nor the use of copper is allowed in the control of late blight. Organic farmers are not able to control the disease, but they can reduce yield loss due to infection by applying pre-sprouting of potato tubers or growing early or (partly) resistant cultivars. From the interviews, we learned that in years with severe outbreaks, many of the Dutch organic farmers did use copper in low doses as foliar fertiliser, which had some effect on preventing or slowing down the infection. Applying copper as fertiliser is allowed in case a low copper content is measured in the soil which is often the case in Dutch landscapes. Within the organic sector, this subject is under debate. For example, one organic farmer said: 'In the past we applied some copper but we rather don't use it. We are not one hundred percent against this method but we don't prefer to use it. I will only apply it in cases with extreme weather'.

How conventional and organic farmers perceive late blight is related to their options for disease control. For organic farmers, late blight is the largest problem in potato production, while conventional farmers name various other pests and diseases that cannot be treated effectively such as bacteria or nematodes. This can be supported by two statements from an organic and a conventional farmer. A conventional farmer mentioned: 'Free-living nematodes are a problem. We have to 
do something about that. Potato late blight has not been a problem the last years because of the large range in crop protection products we can use'. The organic farmer has a different view: 'I am growing organic potatoes for thirty years now and I think potato late blight is the worst disease compared to all other diseases in organic agriculture. We can deal with most of the diseases but late blight gets out of control'. So in the case of late blight, organic farmers feel they have no means to combat the disease while some other pest and diseases can be controlled by for example a broader crop rotation (in the case of nematodes) or hygienic measures. Resistant cultivars are not widely used since only a few varieties are available and the market demands are low.

The way potatoes are cultivated and managed differs for each potato type, and although there is no strict spatial segregation, there are regions where different potato types dominate. Factors related to the management of different potato types that directly affect late blight dynamics are the time of harvesting and the rotation plan. Producers of starch potato usually have a rotation plan with fewer crops (1:2 instead of $1: 3$ or $1: 4)$ which results in a larger risk on initial infection as a result of oospores remaining from a previous potato crop, since these spores can survive in the soil for about 3-4 years (Evenhuis et al. 2007). In the starch potato-producing area in the Netherlands, it was found that the genetic variation in the $P$. infestans population was much larger than in other parts of the Netherlands as a result of oospore-driven epidemics ( $\mathrm{Li}$ et al. 2012). The time of harvesting can affect the spread of $P$. infestans since early harvesting will result in lower potato densities later in the season, which can slow down a late blight epidemic. Compared to starch and ware potatoes, seed potatoes are harvested early in the season (early July). This is also beneficial with respect to late blight since the time exposed to infection is shorter.

Farmers' decision-making is an important aspect influencing disease management. These decisions are influenced by economic incentives which include a trade-off between reducing management costs and limiting the risk of disease damage. Infections can result in reduced yields but also in reduced quality of crop products (Lefebvre et al. 2015). The financial losses related to an infection in a potato field differ per potato production type which results in differences in late blight management. For example, in the Netherlands, seed potatoes have to be certified by an authority (NAK) to be declared to be disease free. An infection in a field of seed potatoes includes a risk that these potatoes will not be certified and cannot be sold as seed potatoes, while $P$. infestans infection in starch potatoes is of less concern since they will be directly processed in a factory. Furthermore, the product price of seed potatoes is higher than for starch potatoes. Therefore, the incentive to adopt more sustainable management strategies, to reduce fungicide use and to save costs is stronger for starch potato growers compared to seed potato growers.
Based on the interviews, also other farmer characteristics were found that probably influence farmers' management strategies such as risk-perception, innovativeness, accuracy and environmental care. Furthermore, farmers in the region also influence each other and they copy each other's behaviour and thus management strategies. Farms are located in a landscape and farmers spend much time on their land so they are well aware how other farmers (successfully) manage their crops. This awareness can also lead to social conflicts in the control of late blight in case of failures to control the disease. $P$. infestans disperses by wind so infections can spread to neighbouring uninfected fields. Therefore, a lot of peer pressure exists around the control of late blight. The introduction of an anonymous hotline as part of the sanitary regulations where farmers can report an infection source increased the tension among farmers and undermined trust and resulted in conflicts in the neighbourhood, as was found in the interviews.

\subsubsection{Stakeholder objectives}

All stakeholders previously described have their own interests, which affect potato late blight management (Table 1). Conflicting interests between stakeholders are observed. For example, many of the stakeholders, including farmers, are commercial entrepreneurs so their main aim is to maximise their profit. Therefore, these stakeholders follow the market demands for specific potato traits, which makes it hard to introduce (new) resistant cultivars as part of late blight control. Furthermore, the agro-chemical industry aims to maximise their profit by developing and marketing fungicides, while research institutes, as well as the government, try to improve sustainability of late blight management, if possible with less fungicides. Many of the strategies proposed are more time and labour demanding and are not in line with farmers' interests since these increase the management costs. For example, current potato production is based on mono-cropping and the machinery used for planting and harvesting cannot be used in intercropping systems. Also, pre-sprouting of seed-tubers or monitoring $P$. infestans populations requires extra work and an investment in equipment. These conflicting interests make it difficult to change the status quo and introduce new strategies in potato late blight management.

\subsection{Fuzzy cognitive mapping}

Based on previous findings, a fuzzy cognitive map was developed. The fuzzy cognitive map shows the important concepts and their relations influencing late blight infection and management (Fig. 2). The goal of the model is to give an overview of the system and to identify strategies and drivers that could positively affect sustainable late blight management. Not all factors mentioned in the ecological and social analysis were 


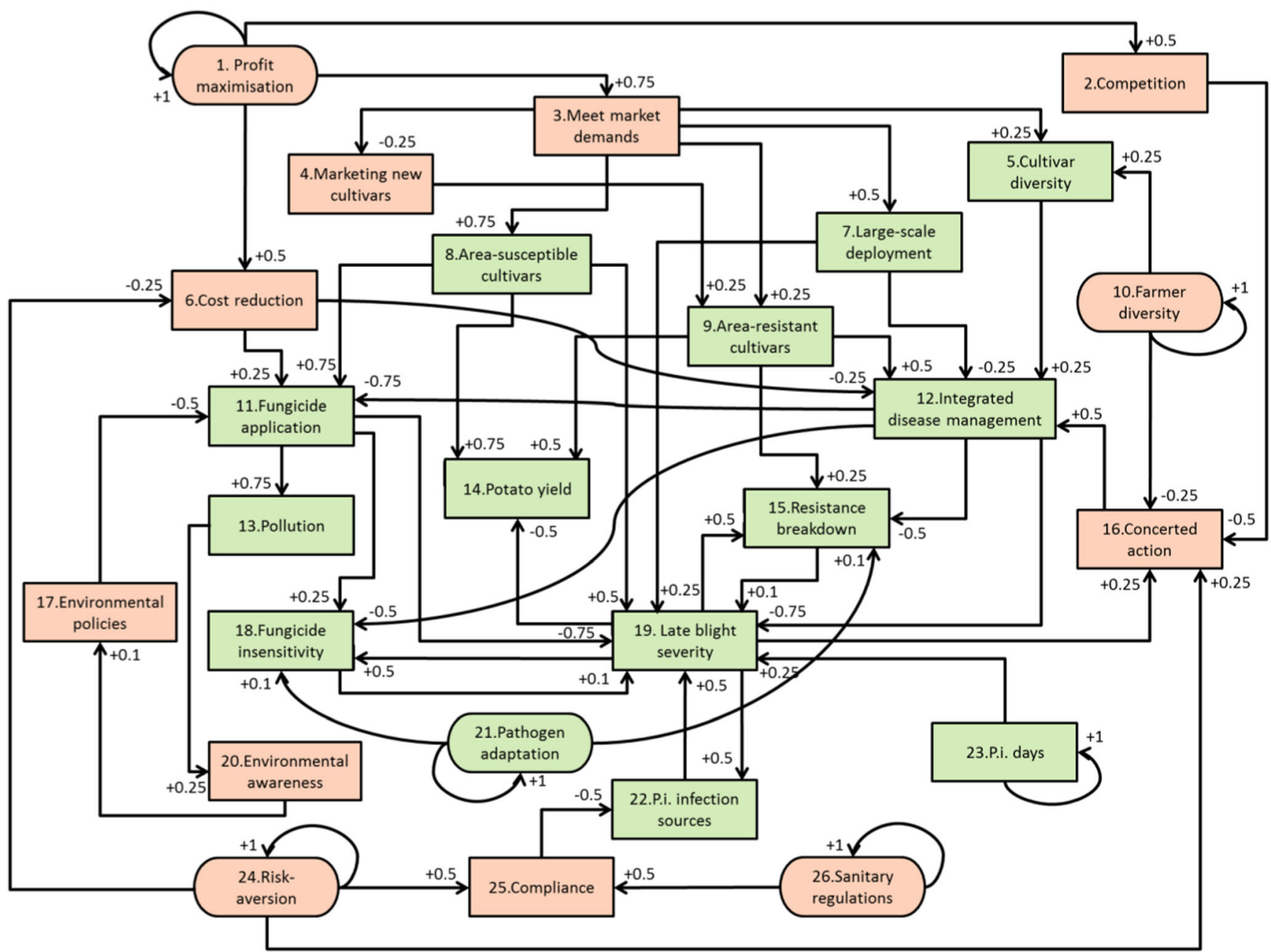

Fig. 2 Fuzzy cognitive map of potato late blight management with the concepts and their relations (arrows). Values next to the arrows indicate influences between concepts, which can be negative or positive (between -1 and +1$)$. The rounded boxes represent external drivers of the system,

included since these were basically too many. Concepts (indicated in italics below) were selected based on importance and some others were combined. Important concepts were those that could have a strong effect on late blight infection and management according to the literature or the social analysis. The factors that were combined included management strategies of potato late blight because these were too many. In the literature, many different management strategies were described which were summarised in two concepts: fungicide application and integrated disease management. Fungicide application represents various types of chemical control, while the concept integrated disease management includes alternative strategies that reduce the use of fungicides. Susceptible and resistant cultivars were separately distinguished in the map since these are two main factors influencing late blight severity. Groups of stakeholders were not included in the map since their relations cannot be captured in positive or negative correlations. Therefore, the social concepts were related to stakeholder objectives, interests and red boxes represent social factors and green boxes represent biophysical/ agronomic factors. P.i. = Phytophthora infestans. A description of the concepts and relations is given in Table 2

interactions that influence management strategies and biophysical factors.

In total, 26 concepts were included in the map and 50 relations (Table 2). The concepts late blight severity, integrated disease management and fungicide application had the higher scores for centrality in the map (Table 2). These three concepts had a relatively high indegree and outdegree, meaning that the concepts are influenced by many variables but also influence other variables themselves. These concepts are influenced by many social, biophysical and agronomic factors and their interactions. Also, feedback loops are observed between biophysical and social factors. For example, late blight severity has a positive effect on concerted action which will increase strategies related to integrated disease management that reduces disease severity. Furthermore, environmental pollution as a result of fungicide application positively influences environmental awareness that leads to environmental policies aiming to reduce fungicide application and environmental pollution. 
Table 2 A description of the concepts and relations included in the fuzzy cognitive map. The numbers between brackets represent the score for centrality of each concept

Concept Description

1. Profit maximisation (3.75)

Within the potato production chain, many of the stakeholders, including farmers, are commercial companies that aim to maximise their profit (Table 1). This external driver leads not only to minimisation of costs related to late blight management but also to competition among stakeholders. Furthermore, demands of the market are followed in order to maximise potato sales.

2 Competition (1.00)

Competition among stakeholders as a result of commercial interests. For example, among farmers to produce the largest yield at low costs and sell the product at the highest price, or between trading/ breeding companies to increase their market shares by releasing new cultivars. Competition among stakeholders makes it difficult to set up collective management strategies.

3. Meet market demands (2.75)

4. Marketing new cultivars $(0.50)$

5. Cultivar diversity $(0.75)$

6. Cost reduction (1.25)

7. Large-scale deployment (1.00)

8. Area-susceptible cultivars (2.75)

9. Area-resistant cultivars (1.75)

10. Farmer diversity (2.50)

11. Fungicide application (4.00)

12. Integrated disease management (4.25)
The market demands are determined by consumers but strongly influenced by (e.g.) retail and the processing and packaging industry. To maximise profit, potato cultivars are produced that meet the market demands to a large extent. Currently, the demand is high for susceptible cultivars and low for resistant cultivars. Each market requires specific potato traits which lead to a large diversity of cultivars grown in the Netherlands. However, a few cultivars supply a large part of the market, which leads to a

Breeding companies develop new cultivars, which have to be introduced to the market. Some of these cultivars are resistant to late blight. Due to the specific market requirements, it is hard to introduce new cultivars.

The number of different cultivars that is grown in a landscape influenced by the market demands and farmer diversity. Increasing cultivar diversity is one of the strategies that are part of integrated disease management.

Cultivation costs, for instance, those related to late blight management incurred for fungicides or labour. The associated costs differ between the two types of late blight management strategies included in the fuzzy cognitive map. Cost reduction has a positive effect on fungicide application since this is relatively easy and cheap, while integrated disease management is negatively affected because this is more labour and knowledge demanding.

A high density of potato and uniform cultivar selection in a landscape as a result of the market demands. A low variety of cultivars negatively affects sustainable strategies since diversity and allocation of cultivars is part of integrated disease management. Furthermore, high potato densities positively affect disease dispersal and corresponding late blight severity.

The area of $P$. infestans-susceptible potato cultivars in a landscape. This is one of the main drivers of fungicide use, late blight severity and potato yield.

The area of $P$. infestans-resistant potato cultivars in a landscape. Resistant cultivars could play a key role in sustainable management of potato late blight and strategies for integrated disease management. However, their yield is lower than for susceptible cultivars, and when they become more widely used, the risk of resistance breakdown increases. Therefore, new resistant cultivars are developed in breeding programmes.

Diversity in the farmer population with organic and conventional as the main two groups but also variation within these groups exists. This diversity leads to different cultivar preferences and a variation of cultivars in the landscape, but also makes concerted action among farmers more difficult.

The amount of fungicides applied for late blight control. This has a strong negative effect on late blight severity but also directly influences environmental pollution. Extensive use can lead to fungicide insensitivity of $P$. infestans.

A combination of strategies to reduce the use of fungicides in late blight management such as pre-sprouting, cultivar resistance, intercropping and resistance management, which can be supported by the use of a DSS. Some of these strategies require or would benefit from cooperation among stakeholders. Integrated disease uniform cultivation in the landscape. 
Table 2 (continued)

Concept Description

13. Pollution (1.00)

14. Potato yield (1.75)

15. Resistance breakdown (1.45)

16. Concerted action (1.75)

17. Environmental policies $(0.60)$

18. Fungicide insensitivity (1.45)

19. Late blight severity (5.45)

20. Environmental awareness (0.35)

21. Pathogen adaptation (2.20)

22. P.i. infection sources (1.25)

23. P.i. days (2.25)

24. Risk-aversion (3.00)

25. Compliance (1.25)

26. Sanitary regulations $(2.50)$ management can be very effective in late blight control and reduces late blight severity, the application of fungicides, resistance breakdown and fungicide insensitivity.

Environmental pollution as a result of fungicide application and positively affects the environmental awareness.

Total potato yield is influenced by the area of susceptible and resistant cultivars and late blight severity.

Breakdown of cultivar resistance to $P$. infestans as a result of pathogen adaptation. The risk for resistance breakdown is influenced by late blight severity, the area of resistant cultivars in a landscape and resistance management practices as part of integrated disease management.

Cooperation of stakeholders in order to achieve sustainable late blight management by using integrated disease management. Competition and diversity of stakeholders negatively affects stakeholder cooperation, while an increase in late blight severity or risk-aversive behaviour increases the willingness to cooperate.

Policies that restrict the use of fungicides in order to reduce the negative effect of fungicides on the environment.

As a result of pathogen adaptation, $P$. infestans can become insensitive to fungicides. This process is positively affected by late blight severity and the use of fungicides and leads to an increase in late blight severity. Integrated disease management strategies can lower the risk on fungicide insensitivity.

The fraction of potato fields infected with late blight in a landscape which is affected by management strategies and epidemiological and biophysical processes. An increase of late blight severity in the landscape decreases potato yield and increases the risk for resistance breakthrough and fungicide insensitivity. An increase in severity positively affects stakeholder cooperation to switch to sustainable disease management strategies.

Societal awareness about the environment as a result of environmental pollution caused by the use of fungicides. This leads to policies to protect the environment from the harmful effect of fungicides.

P. infestans can adapt to the environment by mutation or sexual recombination.

P. infestans infection sources play an important role in outbreaks of the disease. However, late blight severity also leads to more infection sources in a landscape; so, this is a positive feedback loop. If stakeholders comply with the rules, part of these infection sources will be removed.

The number of days with favourable weather for growth and reproduction of $P$. infestans. The weather is one of the most important drivers influencing late blight severity, and because the climatic conditions in the Netherlands are favourable for late blight, this can lead to severe outbreaks.

In decisions on late blight management, risk-perception related to infection plays an important role. When stakeholders are riskaverse, they are more willing to increase management costs, take sanitary precautions and cooperate with other stakeholders in order to lower the risk for infection.

Regulations were introduced related to the removal of infection sources. When farmers do not follow these rules, they can get a fine, which positively affects stakeholder compliance. Riskaversive behaviour also increases compliance because this will reduce the risk for infection or getting a fine.

To prevent early outbreaks of late blight, the government introduced policies related to the removal of infection sources. An inspection was set up to ensure that farmers followed these regulations.
Six external drivers were included in the map: profit maximisation, risk-aversion, farmer diversity and sanitary regulations relate to the social dimension of the system and represent stakeholders' objectives and characteristics, while 
pathogen adaptation and P.i. days (the number of days per year with $P$. infestans favourable weather) are biophysical external drivers. These external drivers don't have to be quantified because their effect is represented by the relations with other concepts.

In total, three different scenarios were analysed by using the fuzzy cognitive map. These three scenarios reflect different ways in which stakeholders involved in potato production and management can influence late blight management and severity in a landscape. The first scenario is a top-down approach in which the government extends the policies related to fungicide use. The second scenario shows the effect of changes in the market demands related to the selection of resistant cultivars. In the third scenario, the effect of stakeholder cooperation was analysed that leads to an increase in concerted action.

An overview of the scenarios and the changes made in the model is as follows:

1. Fungicide restrictions: In the current fuzzy cognitive map, environmental awareness as a result of environmental pollution can lead to an increase in environmental policies that restricts the use of fungicides. However, the positive relation between environment awareness and environmental policies is quite weak. In this scenario, we tested the effect of introducing extra policies to further decrease the use of fungicides. This scenario can relate to an increasing concern about the harmful effect of fungicides on the environment. In the map, this was achieved by adding an extra inflow of +0.5 to the concept environmental policies which represents a strong effect of the introduction of new policies.

2. Change in market demands: As a result of profit maximisation, stakeholders aim to meet the market demands which currently positively affects the area-susceptible cultivars with a value of 0.75 and the area-resistant cultivars with a value of 0.25 . Because markets are used to certain cultivars, it is hard to introduce new ones which is visualised in the fuzzy cognitive map as a negative relation between concept 3 (meet market demands) and 4 (marketing new cultivars). In this scenario, we analysed the effect of a change in the market demands. We assumed that the demand for resistant cultivars strongly increased and is now exactly the opposite as in the previous situation for susceptible and resistant cultivars. For example, this can be the result of an increasing interest of consumers in sustainable food products. In the new situation, we also assumed that the negative effect of the concept meet market demands on marketing of new cultivars has changed from -0.25 to +0.25 which means that new resistant varieties can enter the market.

3. Stakeholder cooperation: In this scenario, we analysed if an increase in cooperation among stakeholders can result in more sustainable management and effective control. In the current situation, concerted action is inhibited by competition and farmer diversity. In the fuzzy cognitive map, concerted action contributes to integrated disease management since some of the strategies require stakeholder cooperation, for example in the case of resistance management that includes spatial allocation of cultivars (susceptible and resistant cultivars, or resistant cultivars containing different resistant genes). But also strategies such as applying cultivars mixtures could benefit from cooperation of stakeholders at a larger scale. For example, the possibility to sell cultivar mixtures to supermarkets would make it economically interesting for farmers to switch to alternative cropping systems. To test the effect of an increase in stakeholder cooperation, an extra influx of 0.5 was added to concerted action.

An overview of the results is shown in Fig. 3. Late blight severity is an important indicator for the effectiveness of disease management in reducing the disease, which can be achieved by chemical control (fungicide application) or a combination of more sustainable management strategies (integrated disease management).

The fuzzy cognitive map for each of the scenarios evolved to a stable equilibrium (Fig. 3), and we compare in particular the relative differences in the equilibrium value of the selected concept to assess the effects of the scenario changes in the fuzzy cognitive maps. In the current situation, the level of fungicide application is relatively high and decreased for all three scenarios, indicating a change in management practices. The scenario of fungicide restrictions leads to lower application of fungicides (Fig. 3b) but also to higher late blight severity (Fig. 3a) since integrated disease management is not increased (Fig. 3c) compared to the current situation. In contrast, a change in market demands could result in a decrease of late blight severity achieved by an increase in integrated disease management and a strong decrease in fungicide application, which would be the most effective scenario with respect to sustainable late blight management. In the third scenario, an increase in concerted action as a result of stakeholder cooperation leads to an increase in integrated disease management, but the level for fungicide application still remains relatively high. However, this leads to the lowest level of late blight severity since integrated disease management as well as fungicide application is used in late blight control.

\subsection{Synthesis}

In this paper, three different methods were used to analyse the components, the interactions and the feedback mechanisms related to late blight management in potato cropping systems in the Netherlands. Current literature on late blight showed that research on its control mainly focusses on agronomic practices, 
Fig. 3 Evolution of consecutive iterations of matrix multiplications on the fuzzy cognitive maps for three concepts (a late blight severity, $\mathbf{b}$ fungicide application and $\mathbf{c}$ integrated disease management). The lines represent the values of these concepts for the current situation and three alternative scenarios (fungicide restrictions, change in market demands and stakeholder cooperation)

\section{A Late blight severity}

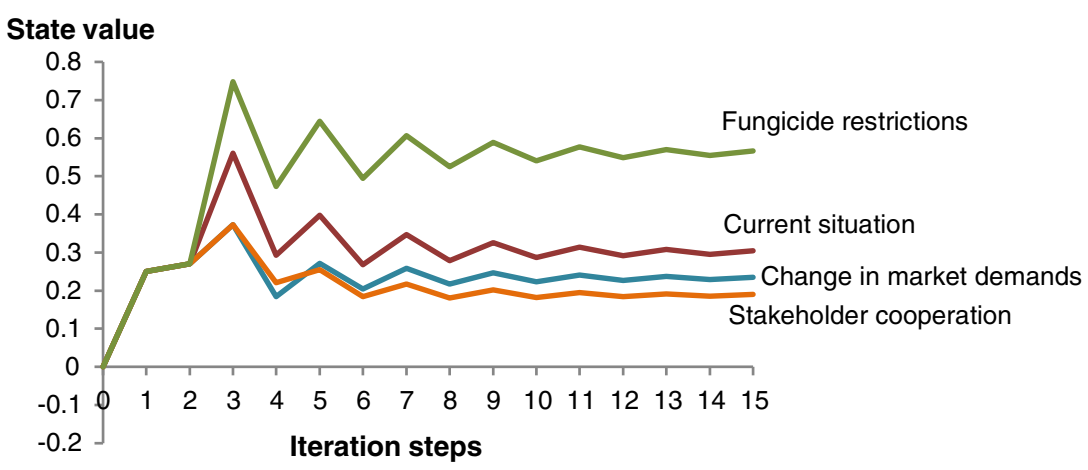

\section{B Fungicide application}

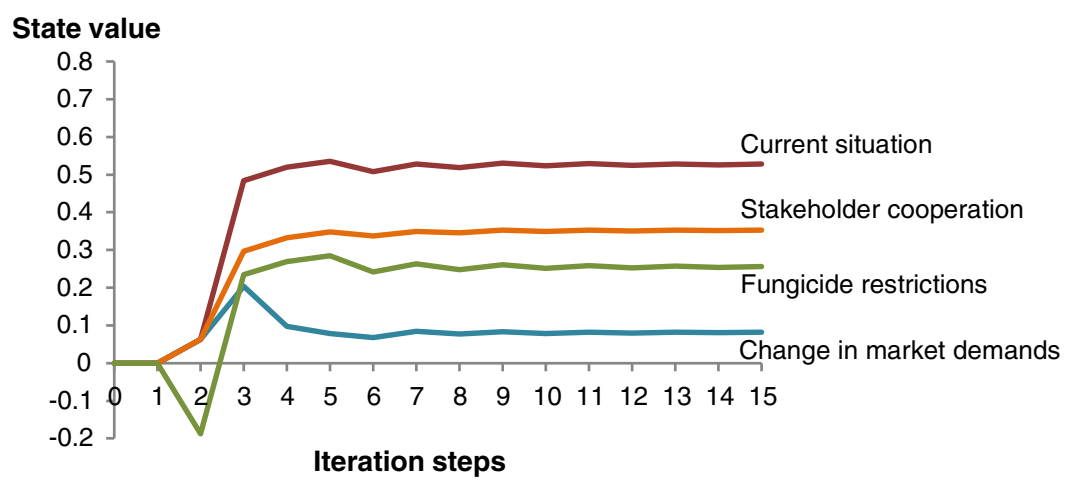

\section{Integrated disease management}

\section{State value}

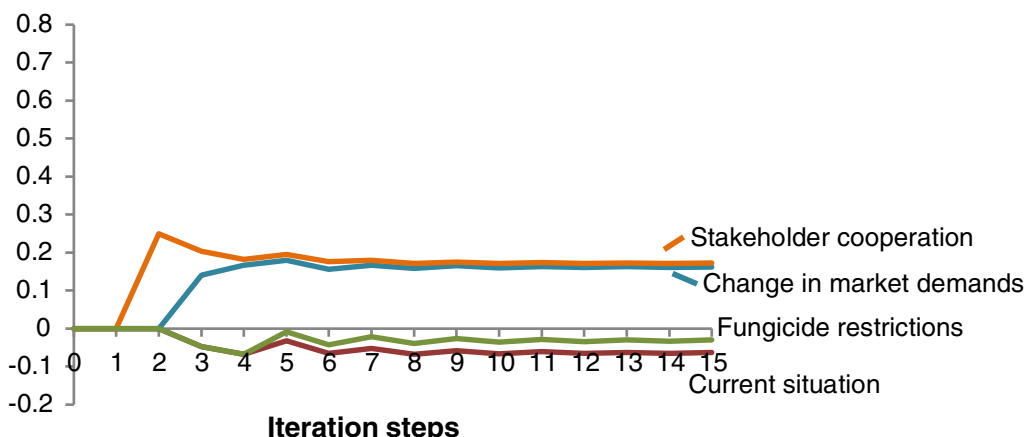

Iteration steps plant breeding for resistance to late blight and chemical-based disease suppression, and the interviews demonstrated that this reflects the most dominant approaches for disease management in practice. These approaches are effective and relatively simple and cheap to implement and support uniform cultivation practices and large-scale deployment of susceptible potato cultivars. As a consequence, they are strongly anchored in potato value chains and the current socio-technical regime (Rip and Kemp 1998; Van Der Ploeg et al. 2007). However, these traditional approaches have a negative effect on the environment and are prohibited in organic cropping systems (Haverkort et al. 2008). More sustainable and more complex strategies such as integrated disease management, cultivar resistance and spatial allocation of cultivars have also been investigated. These strategies could reduce the need for chemical control in late blight management or improve their efficiency. The literature search provided an adequate overview of management strategies but also showed that uncertainties are involved related to responses of $P$. infestans to changes in the environment. For example, knowledge is lacking on the processes that affect resistance breakdown. Another aspect contributing to uncertainty is the effect of climate change on $P$. infestans reproduction because this includes multiple scenarios whose impact is hard to predict. These uncertainties make it difficult for farmers to make reliable decisions on future management strategies of potato late blight (Duru et al. 2015b). 
Besides uncertainties in ecological processes, we are also dealing with a very complex social structure. The different potato value chains and the variation in the farmer population regarding potato management contribute to the system's complexity. Many different stakeholders are involved with each having their own objectives and interests. Most stakeholders have commercial interests and aim to maximise their profits, which can result in several types of interactions such as competition or conflict but also cooperation and trading. The competition and protection of vested interests make it difficult to initialise cooperation among stakeholders to discuss the possibilities regarding sustainable late blight management (Sadok et al. 2008). In addition, decision-making is not a rational process and is influenced by many different factors such as knowledge, attitudes, goals, power and personality (Jager et al. 2000).

An assessment of sustainable potato disease management from a systems perspective requires an analysis of the social and economic viability of alternative, more environmentally benign management strategies. It is important to consider these factors since new management strategies have to be implemented in established production systems, value chains and socio-technical regimes (Duru et al. 2015a). Although technical innovations can emerge, often a description of the required socio-institutional changes for their implementation and out-scaling to system level is lacking. For example, the use of resistant cultivars could play a key role in promoting sustainable management of potato late blight. Socially, this could also decrease conflicts among farmers related to late blight since the risk for infection will become smaller if many farmers would grow resistant cultivars. However, the resistant cultivars currently introduced in the Netherlands do not yet meet the requirements of farmers, the processing and packaging industry and retail. For example, desired yield level and specific cooking type are difficult requirements to meet in combination with disease resistance characteristics. Thus, production of resistant cultivars is not yet economically viable. Part of this could be solved by cooperation among stakeholders in the whole potato production chain. If a large proportion of actors would agree to move towards new type of products (e.g. resistant cultivars or cultivar mixtures) and promote these to customers and consumers, probably economic losses in the production chain could be limited by reducing transaction costs and benefit from the economies of scale. In this case, resistance management strategies are required to reduce the risk of resistance breakdown. Heterogeneity in the deployment of resistance genes in space and time could improve durability, but this requires planning and cooperation among breeding companies and farmers. So in order to achieve sustainable management, orchestration of management and cooperation across the whole production sector would be required (Lefebvre et al. 2015; Veldkamp et al. 2009).
The fuzzy cognitive map was developed on the basis of expert knowledge, to obtain an overview of the system components and to identify actions by stakeholders that could potentially lead to sustainable management. The fuzzy cognitive map showed that social and ecological processes are tightly related and both affect late blight severity, and allowed us to identify feedback loops; for example, an increased late blight severity could lead to concerted action and more sustainable control. After years with severe outbreaks, stakeholders are probably more willing to cooperate to achieve sustainable management of late blight. Moreover, in the fuzzy cognitive map, we could evaluate the potential effects of alternative policy scenarios. It was found that a top-down approach in which the government restricts the use of fungicides increased severity if no alternative strategies are implemented. The current system heavily relies on fungicide application in late blight control, and the fuzzy cognitive map indicates that adoption of alternative strategies would require social-institutional support and facilitation. The other two scenarios showed the effect of increasing stakeholder cooperation and a change in market demands, respectively. Both scenarios decreased late blight severity by an increase in integrated disease management and a decrease in fungicide application, which could mean that focussing on these aspects would be more effective for improving sustainability of late blight management. The shortcomings of fuzzy cognitive maps in the analysis are the difficulty of quantifying the relative importance of the causal relationships among concepts (Kok 2009) and the inability of fuzzy cognitive maps to represent non-linear relations, discrete events and tipping points such as resistance breakdown in the potato late blight system. In this research, fuzzy cognitive mapping was mainly used in a qualitative way: to give an overview of the system and to design scenarios. The output of the model showed the changes in the system in response to several scenarios. However, the results should be interpreted with caution because of the limitations of the method. The results could serve as a basis for discussion with stakeholders to discuss possibilities for alternative management.

To represent non-linear relations, other techniques like agent-based modelling (ABM) would be more suitable (An 2012). ABM allows representing the behaviour of individuals and groups situated in a spatial environment in which biophysical processes occur and to let the system-level patterns emerge from the actions and interactions of these components. In cases where individual components and their behaviours are more or less understood and manageable, ABM could yield policy-relevant results. As a result, ABM is a useful tool to analyse human and natural processes and their interactions (Filatova et al. 2013). Therefore, a logical next step of this research would be to develop an ABM to further analyse the system dynamics. 


\section{Conclusion}

On the basis of the literature review, stakeholder interviews and fuzzy cognitive map presented in this paper, we conclude that potato late blight management is an example of a socialecological system that is driven by many processes and feedback mechanisms that interrelate and interact across multiple temporal and spatial scales. We conclude that a systems approach improves the understanding of the system dynamics which is necessary for developing and deploying effective strategies for controlling P. infestans. Addressing transformations towards sustainable development requires an integrated approach that allows expression of multiple perspectives on the problem, and supports an adaptive planning approach that is open for experimentation and learning (Norton 2008; Westley et al. 2011). The analysis of such systems can be informed by multiple tools, like fuzzy cognitive mapping and agent-based modelling, which allows assessment of the complex interactions within the system and 'serious play' so that the involved stakeholders can experiment and learn. A crucial feature of these tools is that they can incorporate human responses on institutional and environmental change as affected by the implementation of new policies. Such combined modelling techniques help to understand the interactions between social and biophysical processes, which could inform discussions and negotiations among stakeholders and support learning and adaptive planning and decision-making.

Acknowledgments We would like to thank several people that contributed in several ways to this research. First, we would like to thank the people that participated in the interviews, including the farmers, experts and breeding companies. We would like to thank Conner Pelgrim for his help regarding the interviews and we would like to thank Geert Kessel for his suggestions regarding the literature review. Furthermore, we would like to thank the researchers from Wageningen University and Research (WUR) that joined the workshop on fuzzy cognitive mapping, which was really helpful to improve the model. Last, we would like to thank the IP/ OP CAS programme of the WUR for financing this research.

Open Access This article is distributed under the terms of the Creative Commons Attribution 4.0 International License (http:// creativecommons.org/licenses/by/4.0/), which permits unrestricted use, distribution, and reproduction in any medium, provided you give appropriate credit to the original author(s) and the source, provide a link to the Creative Commons license, and indicate if changes were made.

\section{References}

An L (2012) Modeling human decisions in coupled human and natural systems: review of agent-based models. Ecol Model 229:25-36

Andrade-Piedra JL, Hijmans RJ, Forbes GA, Fry WE, Nelson RJ (2005) Simulation of potato late blight in the Andes. I: modification and parameterization of the LATEBLIGHT model. Phytopathology 95(10):1191-1199. doi:10.1094/phyto-95-1191

Andrivon D, Lucas JM, Ellissèche D (2003) Development of natural late blight epidemics in pure and mixed plots of potato cultivars with different levels of partial resistance. Plant Pathol 52(5):586-594. doi:10.1046/j.1365-3059.2003.00882.x

Bengtsson T, Holefors A, Witzell J, Andreasson E, Liljeroth E (2014) Activation of defence responses to Phytophthora infestans in potato by BABA. Plant Pathol 63(1):193-202. doi:10.1111/ppa.12069

CBS (2014) http://www.cbs.nl/nl-NL/menu/home/default.htm. http:// www.cbs.nl/nl-NL/menu/home/default.htm.

Cicore PL, Andreu AB, Huarte MA (2012) Reaction to late blight in response to nitrogen management in Argentine potato cultivars. Crop Prot 42:69-73. doi:10.1016/j.cropro.2012.07.016

Cooke DEL, Lees AK (2004) Markers, old and new, for examining Phytophthora infestans diversity. Plant Pathol 53(6):692-704. doi: 10.1111/j.1365-3059.2004.01104.x

Cooke DEL, Cano LM, Raffaele S, Bain RA, Cooke LR, Etherington GJ, Deahl KL, Farrer RA, Gilroy EM, Goss EM, Grünwald NJ, Hein I, MacLean D, McNicol JW, Randall E, Oliva RF, Pel MA, Shaw DS, Squires JN, Taylor MC, Vleeshouwers VGAA, Birch PRJ, Lees AK, Kamoun S (2012) Genome analyses of an aggressive and invasive lineage of the Irish potato famine pathogen. PLoS Pathogens 8(10). doi:10.1371/ journal.ppat. 1002940

Crosier W (1934) Studies in the biology of Phytophthora infestans (Mont.) de Bary. Cornell University, Ithaca

De Blauwer V, Florins D (2014) Belgisch areaal aardappelen 2014. Landbouwcentrum Aardappelen resultaten 2014. PCA.

De Jong FMW, De Snoo GR (2002) A comparison of the environmental impact of pesticide use in integrated and conventional potato cultivation in The Netherlands. Agric Ecosyst Environ 91(1-3):5-13. doi:10.1016/s0167-8809(01)00262-6

Duru M, Therond O, Fares Mh (2015a) Designing agroecological transitions; a review. Agron Sust Dev :1-21. doi:10.1007/s13593-0150318-x

Duru M, Therond O, Martin G, Martin-Clouaire R, Magne M-A, Justes E, Journet E-P, Aubertot J-N, Savary S, Bergez J-E, Sarthou J (2015b) How to implement biodiversity-based agriculture to enhance ecosystem services: a review. Agron Sust Dev :1-23. doi:10.1007/ s13593-015-0306-1

Evenhuis A, Turkensteen LJ, Raatjes P, Flier W (2007) Monitoring primary sources of inoculum of Phytophthora infestans in The Netherlands 1999-2005. PPO-Spec Rep 12:357

Fall ML, Van der Heyden H, Brodeur L, Leclerc Y, Moreau G, Carisse O (2015) Spatiotemporal variation in airborne sporangia of Phytophthora infestans: characterization and initiatives towards improving potato late blight risk estimation. Plant Pathol 64(1):178190. doi:10.1111/ppa.12235

Filatova T, Verburg PH, Parker DC, Stannard CA (2013) Spatial agentbased models for socio-ecological systems: challenges and prospects. Environ Model Softw 45:1-7

Finckh MR, Schulte-Geldermann E, Bruns C (2006) Challenges to organic potato farming: disease and nutrient management. Potato Res 49(1):27-42. doi:10.1007/s11540-006-9004-3

Fry W (1977) Integrated control of potato late blight-effects of polygenic resistance and techniques of timing fungicide applications. Phytopathology 67(3):415-420

Fry W (2008) Phytophthora infestans: the plant (and R gene) destroyer. Mol Plant Pathol 9(3):385-402

Gachango E, Kirk W, Schafer R, Wharton P (2012) Evaluation and comparison of biocontrol and conventional fungicides for control of postharvest potato tuber diseases. Biol Control 63(2):115-120. doi:10.1016/j.biocontrol.2012.07.005

Garrett KA, Mundt CC (2000) Host diversity can reduce potato late blight severity for focal and general patterns of primary inoculum. Phytopathology 90(12):1307-1312

Gautam HR, Bhardwaj ML, Kumar R (2013) Climate change and its impact on plant diseases. Curr Sci 105(12):1685-1691 
Gisi U, Cohen Y (1996) Resistance to phenylamide fungicides: a case study with phytophthora infestans involving mating type and race structure. Annu Rev Phytopathol 34. doi:10.1146/annurev.phyto.34. 1.549

Glare T, Caradus J, Gelernter W, Jackson T, Keyhani N, Köhl J, Marrone P, Morin L, Stewart A (2012) Have biopesticides come of age? Trends Biotechnol 30(5):250-258

Goodwin SB, Sujkowski LS, Fry WE (1995) Rapid evolution of pathogenicity within clonal lineages of the potato late blight disease fungus. Phytopathology 85(6):669-676

Gossen BD, Carisse O, Kawchuk LM, Van Der Heyden H, McDonald MR (2014) Recent changes in fungicide use and the fungicide insensitivity of plant pathogens in Canada. Can J Plant Pathol 36(3): 327-340. doi:10.1080/07060661.2014.925506

Grünwald NJ, Rubio-Covarrubias OA, Fry WE (2000) Potato late-blight management in the Toluca valley: forecasts and resistant cultivars. Plant Dis 84(4):410-416

Harbaoui K, van der Lee T, Vleeshouwers VGAA, Khammassy N, Harrabi M, Hamada W (2013) Characterisation of Phytophthora infestans isolates collected from potato and tomato crops in Tunisia during 2006-2008. Potato Res 56(1):11-29. doi:10.1007/ s11540-012-9228-3

Haverkort AJ, Boonekamp PM, Hutten R, Jacobsen E, Lotz LAP, Kessel GJT, Visser RGF, Van Der Vossen EAG (2008) Societal costs of late blight in potato and prospects of durable resistance through cisgenic modification. Potato Res 51(1):47-57. doi:10.1007/s11540-0089089-y

Haverkort AJ, Boonekamp PM, Hutten R, Jacobsen E, Lotz LAP, Kessel GJT, Vossen JH, Visser RGF (2016) Durable late blight resistance in potato through dynamic varieties obtained by cisgenesis: scientific and societal advances in the DuRPh project. Potato Res :1-32. doi: 10.1007/s11540-015-9312-6

Hwang YT, Wijekoon C, Kalischuk M, Johnson D, Howard R, Prüfer D, Kawchuk L (2014) Evolution and management of the Irish potato famine pathogen Phytophthora infestans in Canada and the United States. Am J Potato Res 91(6):579-593. doi:10.1007/s12230-0149401-0

Jager W, Janssen MA, De Vries HJM, De Greef J, Vlek CAJ (2000) Behaviour in commons dilemmas: Homo economicus and Homo psychologicus in an ecological-economic model. Ecol Econ 35(3): 357-379

Jochemsen H (2008) An ethical assessment of cisgenesis in breeding late blight resistant potato. Potato Res 51(1):59-73. doi:10.1007/ s11540-008-9090-5

Kankwatsa P, Adipala E, Hakiza JJ, Olanya M, Kidanemariam HM (2002) Effect of integrating planting time, fungicide application and host resistance on potato late blight development in southwestern Uganda. J Phytopathol 150(4-5):248-257. doi:10.1046/j. 1439-0434.2002.00750.x

Kirk WW, Abu-El Samen FM, Muhinyuza JB, Hammerschmidt R, Douches DS, Thill CA, Groza H, Thompson AL (2005) Evaluation of potato late blight management utilizing host plant resistance and reduced rates and frequencies of fungicide applications. Crop Prot 24(11):961-970. doi:10.1016/j.cropro.2004.12.016

Kok K (2009) The potential of fuzzy cognitive maps for semi-quantitative scenario development, with an example from Brazil. Glob Environ Chang 19(1):122-133. doi:10.1016/j.gloenvcha.2008.08.003

Lammerts Van Bueren E, Van Loon JP (2011) De praktijk van kleine kwekers in de aardappelveredeling in Nederland. Louis Bolk Instituut, Driebergen

Lammerts Van Bueren ET, Tiemens-Hulscher M, Struik PC (2008) Cisgenesis does not solve the late blight problem of organic potato production: alternative breeding strategies. Potato Res 51(1):89-99

Lefebvre M, Langrell SH, Gomez-y-Paloma S (2015) Incentives and policies for integrated pest management in Europe: a review. Agron Sustain Dev 35(1):27-45. doi:10.1007/s13593-014-0237-2
Li Y, van der Lee TA, Evenhuis A, van den Bosch GB, van Bekkum PJ, Förch MG, van Gent-Pelzer MP, van Raaij HM, Jacobsen E, Huang SW, Govers F, Vleeshouwers VG, Kessel GJ (2012) Population dynamics of Phytophthora infestans in the Netherlands reveals expansion and spread of dominant clonal lineages and virulence in sexual offspring. G3 (Bethesda, MD) 2(12):1529-1540

Li Y, Van der Lee T, Zhu JH, Jin GH, Lan CZ, Zhu SX, Zhang RF, Liu BW, Zhao ZJ, Kessel G, Huang SW, Jacobsen E (2013) Population structure of Phytophthora infestans in China-geographic clusters and presence of the EU genotype Blue 13. Plant Pathol 62(4):932942. doi:10.1111/j.1365-3059.2012.02687.x

Louwaars N, Dons H, van Overwalle G, Raven H, Arundel A, Eaton D, Nelis A (2009) Breeding business : the future of plant breeding in the light of developments in patent rights and plant breeder's rights. CGN report;14 (EN). Centre for Genetic Resources (CGN), Wageningen

Lozoya-Saldaña H, Coyote-Palma MH, Ferrera-Cerrato R, LaraHernández ME (2006) Microbial antagonism against Phytophthora infestans (Mont) de Bary. Agrociencia 40(4):491-499

McCown RL (2002) Locating agricultural decision support systems in the troubled past and socio-technical complexity of 'models for management'. Agric Syst 74(1):11-25. doi:10.1016/s0308-521x(02) 00020-3

Merk M, Frechen T, Gold RE, Schiffer H, Levy T, Saramago J (2011) INITIUM®: a new innovative fungicide of a new chemical class for the control of late blight and downy mildew diseases. Acta Horticulturae 917.

Mizubuti ESG, Fry WE (1998) Temperature effects on developmental stages of isolates from three clonal lineages of Phytophthora infestans. Phytopathology 88(8):837-843

Mizubuti ESG, Aylor DE, Fry WE (2000) Survival of Phytophthora infestans sporangia exposed to solar radiation. Phytopathology 90(1):78-84

Möller K, Reents HJ (2007) Impact of agronomic strategies (seed tuber pre-sprouting, cultivar choice) to control late blight (Phytophthora infestans) on tuber growth and yield in organic potato (Solanum tuberosum L.) crops. Potato Res 50(1):15-29. doi:10.1007/ s11540-007-9026-5

Mundt CC, Cowger C, Garrett KA (2002) Relevance of integrated disease management to resistance durability. Euphytica 124(2):245252. doi:10.1023/a:1015642819151

Nærstad R, Hermansen A, Bjor T (2007) Exploiting host resistance to reduce the use of fungicides to control potato late blight. Plant Pathol 56(1):156-166. doi:10.1111/j.1365-3059.2006.01491.x

Norton BG (2008) Beyond positivist ecology: toward an integrated ecological ethics. Sci Eng Ethics 14(4):581-592. doi:10.1007/s11948008-9095-0

Olanya OM, Larkin RP (2006) Efficacy of essential oils and biopesticides on Phytophthora infestans suppression in laboratory and growth chamber studies. Biocontrol Sci Tech 16(9):901-917. doi:10.1080/ 09583150600827918

Olanya OM, Ojiambo PS, Nyankanga RO, Honeycutt CW, Kirk WW (2009) Recent developments in managing tuber blight of potato (Solanum tuberosum) caused by Phytophthora infestans. Can J Plant Pathol 31(3):280-289. doi:10.1080/07060660909507602

Özesmi U, Özesmi SL (2004) Ecological models based on people's knowledge: a multi-step fuzzy cognitive mapping approach. Ecol Model 176(1-2):43-64. doi:10.1016/j.ecolmodel.2003.10.027

PA (2008) Verordening PA bestrijding phytophthora infestans bij aardappelen 2008. The Netherlands

Park TH, Vleeshouwers VGAA, Kim JB, Hutten RCB, Visser RGF (2005) Dissection of foliage and tuber late blight resistance in mapping populations of potato. Euphytica 143(1-2):75-83. doi:10. 1007/s10681-005-2658-0

Peters RD, Al-Mughrabi KI, Kalischuk ML, Dobinson KF, Conn KL, Alkher H, Islam MR, Daayf F, Lynn J, Bizimungu B, De Koeyer 
D, Lévesque CA, Kawchuk LM (2014) Characterization of Phytophthora infestans population diversity in Canada reveals increased migration and genotype recombination. Can J Plant Pathol 36(1):73-82. doi:10.1080/07060661.2014.892900

Rauscher GM, Smart CD, Simko I, Bonierbale M, Mayton H, Greenland A, Fry WE (2006) Characterization and mapping of RPi-ber, a novel potato late blight resistance gene from Solanum berthaultii. Theor Appl Genet 112(4):674-687. doi:10.1007/s00122-005-0171-4

Rebaudo F, Dangles O (2012) An agent-based modeling framework for integrated pest management dissemination programs. Environ Model Softw 45:141-149

Rip A, Kemp R (1998) Technological change. In: Rayner S, Malone EL (eds) Human choice and climate change, 2. Battelle, Columbus, pp 327-399

Sadok W, Angevin F, Bergez J-É, Bockstaller C, Colomb B, Guichard L, Reau R, Doré T (2008) Ex ante assessment of the sustainability of alternative cropping systems: implications for using multi-criteria decision-aid methods. A review. Agron Sustain Dev 28(1):163174. doi:10.1051/agro:2007043

Schaap BF, Blom-Zandstra M, Hermans CML, Meerburg BG, Verhagen J (2011) Impact changes of climatic extremes on arable farming in the north of the Netherlands. Reg Environ Chang 11(3):731-741

Schöber B (1992) Control of late blight, Phytophthora infestans, in integrated crop management. Neth J Plant Pathol 98(2 Supplement): 251-256

Shanthiyaa V, Saravanakumar D, Rajendran L, Karthikeyan G, Prabakar K, Raguchander T (2013) Use of Chaetomium globosum for biocontrol of potato late blight disease. Crop Prot 52:33-38. doi:10. 1016/j.cropro.2013.05.006

Shtienberg D (2013) Will decision-support systems be widely used for the management of plant diseases? Annu Rev Phytopathol 51. doi:10. 1146/annurev-phyto-082712-102244

Skelsey P, Rossing WAH, Kessel GJT, Van Der Werf W (2009) Scenario approach for assessing the utility of dispersal information in decision support for aerially spread plant pathogens, applied to Phytophthora infestans. Phytopathology 99(7):887-895. doi:10.1094/phyto-99-70887

Skelsey P, Rossing WAH, Kessel GJT, Van Der Werf W (2010) Invasion of Phytophthora infestans at the landscape level: how do spatial scale and weather modulate the consequences of spatial heterogeneity in host resistance? Phytopathology 100(11):1146-1161. doi:10. 1094/phyto-06-09-0148

Staal L, Vaal M, Dusseldorp A (2014) Bestrijdingsmiddelen: gewasbeschermingsmiddelen en biociden : GGD informatieblad medische milieukunde. Rijksinstituut voor Volksgezondheid en Milieu, Bilthoven

Tamm L, Thürig B, Bruns C, Fuchs JG, Köpke U, Laustela M, Leifert C, Mahlberg N, Nietlispach B, Schmidt C, Weber F, Fließbach A (2010) Soil type, management history, and soil amendments influence the development of soil-borne (Rhizoctonia solani, Pythium ultimum) and air-borne (Phytophthora infestans, Hyaloperonospora parasitica) diseases. Eur J Plant Pathol 127(4): 465-481. doi:10.1007/s10658-010-9612-2

Tan MYA, Hutten RCB, Visser RGF, van Eck HJ (2010) The effect of pyramiding Phytophthora infestans resistance genes RPi-mcd1 and RPi-ber in potato. Theor Appl Genet 121(1):117-125

Thierfelder C, Cheesman S, Rusinamhodzi L (2013) Benefits and challenges of crop rotations in maize-based conservation agriculture (CA) cropping systems of southern Africa. Int J Agric Sustain 11(2):108-124. doi:10.1080/14735903.2012.703894

Tiemens-Hulscher M, Delleman J, Eising J, Lammerts van Bueren E (2013) Potato breeding: a practical manual for the potato chain. Potato World Magazine, The Hague

Turkensteen LJ, Flier WG, Wanningen R, Mulder A (2000) Production, survival and infectivity of oospores of Phytophthora infestans. Plant Pathol 49(6):688-696. doi:10.1046/j.1365-3059.2000.00515.x

Van den Hurk B, Siegmund P, Klein Tank A, Attema J, Bakker A, Beersma J, Bessembinder J, Boers R, Brandsma T, van den Brink H, Drijfhout S, Eskes H, Haarsma R, Hazeleger W, Jilderda R, Katsman C, Lenderink G, Loriaux J, Van Meijgaard E, Van Noije T, Van Oldenborgh GJ, Selten F, Siebesma P, Sterl A, De Vries H, Van Weele M, De Winter R, Van Zadelhoff G (2014) KNMI'14: climate change scenarios for the 21 st century - a Netherlands perspective. Scientific Report WR2014-01 KNMI, De Bilt

Van Der Ploeg JD, Groot JCJ, Verhoeven FPM, Lantinga EA (2007) Interpretation of results from on-farm experiments: manurenitrogen recovery on grassland as affected by manure quality and application technique. 2. A sociological analysis. NJAS - Wagening J Life Sci 54(3):255-268

Van Der Werf HMG (1996) Assessing the impact of pesticides on the environment. Agric Ecosyst Environ 60(2-3):81-96. doi:10.1016/ s0167-8809(96)01096-1

Veldkamp A, Van Altvorst AC, Eweg R, Jacobsen E, Van Kleef A, Van Latesteijn H, Mager S, Mommaas H, Smeets PJAM, Spaans L, Van Trijp JCM (2009) Triggering transitions towards sustainable development of the Dutch agricultural sector: TransForum's approach. Agron Sustain Dev 29(1):87-96. doi:10.1051/agro:2008022

Westley F, Olsson P, Folke C, Homer-Dixon T, Vredenburg H, Loorbach D, Thompson J, Nilsson M, Lambin E, Sendzimir J, Banerjee B, Galaz V, Van Der Leeuw S (2011) Tipping toward sustainability: emerging pathways of transformation. Ambio 40(7):762-780. doi: 10.1007/s13280-011-0186-9

Wharton PS, Kirk WW, Baker KM, Duynslager L (2008) A web-based interactive system for risk management of potato late blight in Michigan. Comput Electron Agric 61(2):136-148. doi:10.1016/j. compag.2007.10.002

Zwankhuizen MJ, Zadoks JC (2002) Phytophthora infestans's 10-year truce with Holland: a long-term analysis of potato late-blight epidemics in the Netherlands. Plant Pathol 51(4):413-423 